\title{
Aqueous angiography guided ab interno trabecular surgery for open-angle glaucoma
}

\author{
Tanuj Dada, Anand Naik Bukke
}

Ophthalmology, RPCentre for Ophthalmic Sciences, AlIMS, New Delhi, India

Correspondence to Dr Anand Naik Bukke; naikanand6461@gmail.com

Accepted 10 December 2021

D) Check for updates

(c) BMJ Publishing Group Limited 2022. No commercial re-use. See rights and permissions. Published by BMJ.

\begin{tabular}{|l|}
\hline To cite: Dada T, \\
Bukke AN. BMJ Case \\
Rep 2022;15:e248261. \\
doi:10.1136/bcr-2021- \\
248261 \\
\hline
\end{tabular}

\section{DESCRIPTION}

We present a novel technique to aid in decision making during minimally invasive glaucoma surgery. The aqueous outflow pathways are imaged using aqueous angiography and then the site of maximal outflow is localised to perform ab interno trabecular surgery. ${ }^{1}$ A 53 -year-old man presented to our glaucoma clinic with diagnosis of pseudophakia with glaucoma with intraocular pressure (IOP) of left eye $26 \mathrm{~mm} \mathrm{Hg}$ (on four topical medications) and vertical cup disc diameter ratio of $0.9: 1$. Aqueous angiography was performed using FLEX module Spectralis HRA+OCT (Heidelberg Engineering GmbH, Heidelberg, Germany) after indocyanine green $(0.5 \%)$ injection into the anterior chamber, to visualise the main aqueous outflow channels. ${ }^{2}$ An outflow channel in the nasal quadrant was identified as the region of maximal flow ${ }^{3}$ (figure 1) and the trabecular meshwork was excised for $30^{\circ}$ in the same area using a bent $26 \mathrm{G}$ needle (BANG-bent ab interno needle goniectomy). The dye was reinjected to evaluate the increase in outflow after trabecular meshwork (TM) removal (figure 2). Postoperative day 1 left eye IOP was $10 \mathrm{~mm} \mathrm{Hg}$ and $12 \mathrm{~mm} \mathrm{Hg}$ at 1 week (on three topical medications).

This technique highlights the beginning of a new era in glaucoma surgery with the use of aqueous angiography to facilitate focal surgery on the Schlemm's canal adjacent to an outflow channel, avoiding unnecessary tissue damage

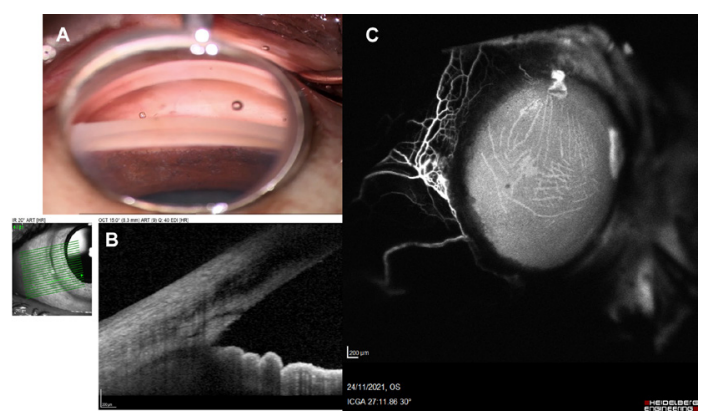

Figure 1 (A) Pre-bent ab interno needle goniectomy (BANG) gonioscopy showing open angle with trabecular meshwork and prominent iris processes. (B) Anterior segment optical coherence tomography (ASOCT) of angle of the same showing trabecular meshwork (TM) with a canal of Schlemm (SC). (C) Indocyanine green angiograph (ICG) guided pre-BANG aqueous drainage with a prominent nasal network of aqueous channels.

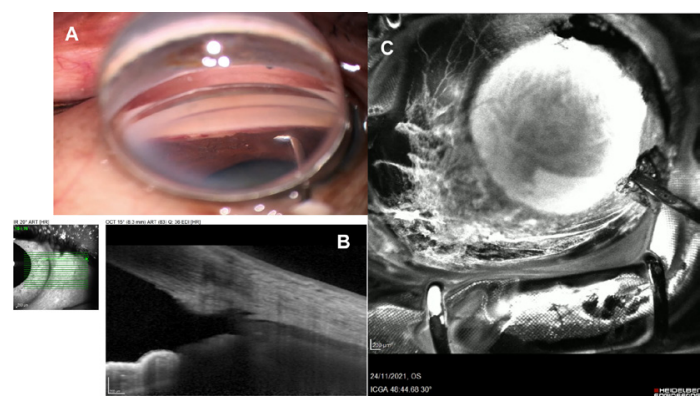

Figure 2 (A) Post-bent ab interno needle goniectomy (BANG) gonioscopy showing the white area where a strip of trabecular meshwork (TM) has been removed in the angle. (B) Anterior segment optical coherence tomography (ASOCT) of angle post-BANG showing excised TM with open Schlemm (SC). (C) Indocyanine green angiograph (ICG) post-BANG with accentuated aqueous drainage through nasal network of aqueous channels.

\section{Learning points}

- This novel technique highlights the beginning of a new era in glaucoma surgery by using aqueous angiography to target the maximal aqueous outflow channels thereby reduces unwanted tissue damage.

- Helps in decision making in minimally invasive glaucoma surgeries.

by operating on a wider circumference of the canal. ${ }^{4}$

Contributors AN was involved in data acquisition, manuscript drafting, preparation and intellectual input and approved the first manuscript. TD was involved in performing the novel technique, intellectual input and approved the final manuscript.

Funding The authors have not declared a specific grant for this research from any funding agency in the public, commercial or not-for-profit sectors.

Competing interests None declared.

Patient consent for publication Consent obtained directly from patient(s).

Provenance and peer review Not commissioned; externally peer reviewed.

Case reports provide a valuable learning resource for the scientific community and can indicate areas of interest for future research. They should not be used in isolation to guide treatment choices or public health policy. 
Images in...

\section{REFERENCES}

1 Huang AS, Saraswathy S, Dastiridou A, et al. Aqueous angiography-mediated guidance of trabecular bypass improves angiographic outflow in human enucleated eyes. Invest Ophthalmol Vis Sci 2016;57:4558-65.

2 Huang AS, Camp A, Xu BY, et al. Aqueous angiography: aqueous humor outflow imaging in live human subjects. Ophthalmology 2017;124:1249-51.
3 Huang AS, Penteado RC, Saha SK, et al. Fluorescein aqueous angiography in live normal human eyes. J Glaucoma 2018;27:957-64.

4 Dada T, Mahalingam K, Bhartiya S. Minimally invasive glaucoma Surgery-to remove or preserve the trabecular meshwork: that is the question? J Curr Glaucoma Pract; 15:47-51.

Copyright 2021 BMJ Publishing Group. All rights reserved. For permission to reuse any of this content visit

https://www.bmj.com/company/products-services/rights-and-licensing/permissions/

BMJ Case Report Fellows may re-use this article for personal use and teaching without any further permission.

Become a Fellow of BMJ Case Reports today and you can:

- Submit as many cases as you like

- Enjoy fast sympathetic peer review and rapid publication of accepted articles

- Access all the published articles

- Re-use any of the published material for personal use and teaching without further permission

\section{Customer Service}

If you have any further queries about your subscription, please contact our customer services team on +44 (0) 2071111105 or via email at support@bmj.com.

Visit casereports.bmj.com for more articles like this and to become a Fellow 